\title{
COUNSELLING, VOCATIONAL INTEREST AND SOCIO- ECONOMIC STATUS AS CORRELATES OF RE-ENTRY OF GIRLS INTO SCHOOL IN EDO STATE
}

\author{
Alika, ljeoma Henrietta \\ Department of Educational Psychology and Curriculum Studies \\ Faculty of Education \\ University of Benin \\ Benin City
}




\section{Abstract}

The study investigated the relationship between counselling, vocational interest and socio-economic status on re-entry of girls into schools in Edo State. The research design adopted was corelational because it sought to establish the relationship between the independent variables and the dependent variable. One research hypothesis was formulated to guide this study. Four research instruments were used: they are the instrument on counselling, the modified Bakare Vocational Interest Inventory, the instrument on socio-economic status of parents and the instrument on reasons for re-entry into school by girls. Three continuing education schools were randomly selected for the study. Three hundred and twenty girls who re-enrolled in these schools were used for the study. Data was analysed using multiple regression analysis method. Results showed that there is a significant relationship between counselling, vocational interest and socio-economic status of parents on re-entry of girls into school. It is recommended that counselling services should be provided for girls who have dropped out of school with a view to getting them back into the school system. Vocational guidance should be taught in schools and more income generating projects should be put in place by government and nongovernmental agencies to improve the living standard of the people.

Key Words: Counselling, Vocational Interest, Socioeconomic Status, Re-entry, Girls, School.

\section{Introduction}

Education has been perceived to be a vital instrument in improving the status of the girl child. Consequently, there have been efforts to improve the access of girls and women to education. To demonstrate their concern for the education of the girl child, world leaders at the 1990 world summit for children, reaffirmed their commitment to reducing the disparities that existed in the rates of 
school enrolment between boys and girls. In addition, a United Nations International Children Educational Fund report (UNICEF, 2004) showed that 65 million girls are out of school, hence UNICEF has launched a programme that will accelerate interest and progress in girls' education. It is called United Nations Girls Initiative Programme. To effectively remove the barriers that prevent girls from accessing education, succeeding in and completing school, societies and schools will have to deal with factors that are fundamental to the quality of education given to the girl and societal perception of educating the girl child. Counsellors have a role to play in ensuring successful completion of the education of the adolescent girls. Alika and Egbochuku (2007) found that there is a significant relationship between counselling and re-entry of girls into school. Counsellors should assist in public enlightenment on the benefits of educating the girl child. Efforts made to ensure that adolescent girls who re-entered school are retained with a view to acquiring education will, according to Egbochuku (2002), permanently close the door to poverty and ignorance and at the same time open that of prosperity in terms of economic buoyancy, social advancement and civilization. Efforts geared towards studying factors that are responsible for re-entry of girls into school, with a view to ensuring that they complete their schooling, will go a long way in ensuring that their innate potentials are harnessed and developed, hence it has been stated in the national policy on Education (FGN, 2004) that:

Education will continue to be highly rated in national development plans because education is the most important instrument of change, any fundamental change in the intellectual and social out look of any society has to be preceded by an educational revolution $(: 8)$

As observed in the statement above, education will be highly rated in national development plans including the education of the girl child. In as much as education has been recognized as the 
bedrock for the development of a nation, certain factors subsumed in historical, religious, cultural, socio-economic and school related factors affect the girl child's access to education in Nigeria (Osakwe, Osagie, Madunagu and Usman, 1999). Also studies have shown that counselling, supportive family, development of perseverance, increased motivation, positive relationship between staff and students, satisfaction with learning experiences and fair discipline policies are some of the reasons for re-entry and staying in school (Christenson, Sinclair, Lehr \& Hurley, 2000). Super (1957) asserted that reality factors play an increasingly important role in vocational choice with increasing age from early adolescence to adulthood. Mcmillen (1993) also observed that as the socio-economic status of parents rises, the incidence of dropout is reduced and by implication the possibility of re-entry into school is enhanced. Abiri (1979), in a study, observed that Nigerian Youths are known to be mostly interested in fanciful and prestigious occupations; he therefore, advocated counselling. A recent study by Egbochuku and Alika (2008), found that there is a positive significant relationship between socio-economic status of parents and vocational interest of girls on re-entry in school by girls in Edo State. Realizing the importance of re-entry and completing school, the Federal Government of Nigeria in her Universal Basic Education Programme (1999), stated some of her objectives as follows:

Catering for the learning needs of the young persons who, for one reason or other, have had to interrupt their schooling through appropriate forms of complementary approaches to the provision and promotion of basic education (:7).

From the foregoing, the importance of re-entry into school by girls who had to interrupt their schooling as a result of one problem or the other cannot be over-emphasized. It is the concern of government that provision should be made for them to re-enter and complete school. The purpose of this study therefore, is to find out 
the relationship between counselling, vocational interest and socioeconomic status on re-entry of girls into school in Edo State.

\section{The Problem}

The concern shown by government and non-governmental agencies about the education of the girl child is an issue of social justice, in that girl child education has been affected by cultural historical, religious, socio-economic status and even school related factors over the years. (Osakwe, Osagie, Madunagu, Usman 1999). As Egbochuku (2000), rightly observed, education is an enabling tool that equips the individual to find solution to the problems of society. In fact, there is a growing interest in the education of girls who dropped out of school in contemporary African Nations. In Nigeria, government is determined to resolve this problem, in that the National Policy on Education (FGN, 2004) has made provisions for school dropouts who may wish to re-enter school. In fact, it is the awareness in the multiplier effect of the education of the girl child and a desire to find out reasons for re-entry of girls into school that has motivated this study. Could it be said that counselling, vocational interest and socio-economic status have any relationship with re-entry of girls into school? The desire to find answers to the questions above has motivated this study. One hypothesis was therefore formulated to guide the study.

\section{Hypothesis}

There is no significant relationship between counselling, vocational interest and socio-economic status on re-entry of girls into schools in Edo State.

\section{Method of Study}

The survey method was adopted for this study. The study was correlational in nature because the study investigated the extent of relationship between the independent variables and the dependent variable. The population of the study comprises all girls who dropped out of school and re-enrolled. Three institutes of 
continuing education were randomly selected for the study, from the five institutes in the state. Sample size of 360 girls who dropped out of school and re-enrolled in these institutes were randomly selected for the study. This represented 120 females from each institute. The average age of females were (mean $=21$ years and a standard deviation of $S D=4.73$ ). Four research instruments were used for the study, they are (1) the instrument on counselling (2) the modified Bakare vocational interest inventory (3) the instrument on socioeconomic status of parents and (4) the instrument on reasons for reentry into school by girls.

\section{Results}

Data were analysed using multiple regression analysis. The alpha level of significance was set at 0.05 .

Table 1 reveals that the multiple $R$ for this model was .605 . The joint impact of counselling, vocational interest and socioeconomic status accounted for $35 \%$ (i.e. $R^{2}$ (adj) .359) variation in re-entry of girls into school. The beta weight for counselling was .170 , vocational interest was .300 while socio-economic status was .410. In order to show the significance of the predictive power of each independent variable, their regression coefficients were computed using the student t statistics. These variables were tested at 0.05 level of confidence. The $t$ values are as follows (counselling 3.531, vocational interest 5.952, and socio-economic status -8.202). This shows that both variables had significant relationship with reentry of girls into schools, though socio-economic status was negatively significant. It should be noted that the three variables are good predictors of re-entry of girls into school with an $\mathrm{F}$ value $=$ 54.556. The regression model for this function is re-entry of girls = $20.423+.193$ counselling +.185 vocational interest -9.915 socioeconomic status. 
Table I: Regression analysis of counselling, vocational interest and socio-economic status on Re-entry of girls into school

\begin{tabular}{|lc}
\hline Multiple R. & 605 \\
R. Square & 366
\end{tabular}

Adjusted $r^{2} \quad 359$

Standard error 9.29.9

\begin{tabular}{|l|l|l|l|l|l|}
\hline \multicolumn{7}{|c|}{ ANOVA } \\
\hline & SS & Df & Ms & F & Sig. \\
\hline Regression & 14130.614 & 3 & 4710.205 & 54.556 & .000 \\
\hline Residual & 24515.164 & 284 & 86.321 & & \\
\hline Total & 38645.778 & 287 & & & \\
\hline \multicolumn{7}{|c|}{ PARAMETER ESTIMATES } \\
\hline \multicolumn{7}{|c|}{ Std } & Beta & t & Sig \\
\hline Counselling & B 193 & .055 & .170 & 3.531 & .000 \\
\hline $\begin{array}{l}\text { Vocational } \\
\text { interest }\end{array}$ & .185 & .031 & .300 & 5.952 & .000 \\
\hline $\begin{array}{l}\text { Socio- } \\
\text { economic } \\
\text { status }\end{array}$ & -9.915 & 1.209 & -.410 & -8.202 & .000 \\
\hline Constant & 20.423 & 4.781 & & & \\
\hline
\end{tabular}

Regression significant at $p<0.05$

The hypothesis which states that there is no significant relationship between counselling, vocational interest and socioeconomic status on re-entry of girls into school in Edo State is therefore rejected. It is concluded that there is a significant relationship between counselling, vocational interest and socioeconomic status on re-entry of girls into school in Edo State.

\section{Discussion of Results}

The findings of the study revealed that there is a significant relationship between counselling, vocational interest and socioeconomic status on re-entry of girls into school. The findings give credence to the vital role that counselling plays in re-entry into school by girls. It is in agreement with the findings of Wilson (1997) 
who found that when the academic records of 562 students who had requested for counselling for personal concerns during a I-year programme were examined to determined academic outcome. Students receiving counselling enjoyed a $14 \%$ retention advantage over non-counselled students. Boyd (1997) reported a similar finding using students who were academically dismissed at the end of the 1994 spring semester, they received an invitation to participate in a summer programme designed to teach some skills necessary for academic success. The treatment group comprised of 133 participants, 98 of whom were subsequently approved for reinstatement, thus, buttressing the efficacy of counselling. The findings of this study give credence to the vital role vocational interest and socio-economic status could play in determining reentry into school. Super (1957) found that with increasing age reality factors play an increasingly important role in vocational choice from early adolescence to adulthood. Uba (1983) asserts that whoever enters a particular occupation is usually influenced by the socioeconomic class or level of the parents. This in turn, is strongly affected by parent's vocation. He further contributed that there is an interesting variable of the educational ladder in which children of the middle and upper social class families find easier to climb. This, according to him, is the provision of a conducive environment that will enhance the child's vocational ambition. Shertzer and Stone (1976) found that socio-economic status of the family influences the vocational preference of youths. They postulated that a child's particular socio-economic inheritance may have direct and important effect on the occupations / vocations open or attractive to him/her.

\section{Implication for Counselling}

Government should, as a matter of urgency, ensure that counsellors are posted to all schools in the federation.

Counsellors should enlighten the public through jingles in television and radio on the benefits derivable from educating the girl child. Counsellors should identify indigent students, who are likely to dropout of school as a result of poverty, and help negotiate some 
form of scholarship or assistance for them. Vocational counsellors should enlighten students on the importance of the various vocations and the entry requirements. This could be done by organizing career day and career games.

Girls who re-entered school should be given individual and persona-social counselling in order to realize and harness their potentials.

\section{Conclusion and Recommendations}

This study investigated the relationship between counselling, vocational interest and socio-economic status on re-entry of girls into school. The conclusion drawn from the study is that counselling, vocational interest and socio-economic status significantly determine re-entry into school by girls in Edo State. In other words, the provision of counselling services greatly enhances re-entry into school by girls. Moreover, the economic and occupational levels of the home may affect the vocational goals of the girls by influencing their aspirations, and by discouraging aspirations that are much below parental occupational status.

It is recommended therefore, based on the findings of the study, that counselling services should be provided for girls who reenrolled in schools and girls who are at risk of dropping out of school with a view to ensuring that they get well adjusted in the school system. There should be public enlightenment in the print and electronic media on programmes aimed at eliminating cultural, social and economic barriers to the education of girls. In addition, government and non-governmental agencies should create more programmes, providing more income generating programmes, like the establishment of small-scale industries. Finally, there should be public enlightenment on the benefits derivable in the education of the girl-child, in view of the multiplier and intergenerational benefits derivable in the education of the girl-child. 


\section{References}

Abiri, J. O. (1979). The educational attitudes of some Nigerian Adolescent grammar school pupils, West African Journal of Education, 19, 55 - 59.

Alika, H. I. \& Egbochuku, E. O. (2007), Counselling as a correlate of Re-entry of girls into school in Edo State. Journal of Studies in Education. Faculty of Education, Ambrose Alli University, Ekpoma.

Bakare, G. C. M. (1977), Vocational interest inventory, Ibadan Psychological Research Publication.

Boyd, V. (1997), A Summer Retention Programme for students who were academically dismissed and applied for reinstatement. Research Report No. 13 - 96. Counselling Centre, Maryland University College Park.

Christenson, S. L., Sinclair, M.F., Lehr, C.A., \& Hurley, C.M. (2000). Promoting successful completion. In D. Minke \& G. Bear (Eds), Preventing School Problems - Promoting School Success: Strategies and Programme that work, Bethesda, M.D. National Association of School Psychologists.

Egbochuku, E. O. (2000). Counsellors as facilitators for the successful implementation of the universal basic education scheme in Nigeria, in J.A. Aghenta and D. Awanbor, (Eds). The Nigerian Academy of Education Proceedings of the $15^{\text {th }}$ Annual Congress of the Nigerian Academy of Education. Ambik Press Limited, Benin City. $359-370$.

Egbochuku, E. O. and Alika H. I. (2008). Socio-economic status and vocational interest as correlates of re-entry of girls into schools in Edo State. Benin Journal of gender studies 1 (1) $31-36$.

Federal Republic of Nigeria (2004). National Policy on education . Yaba Rev. ed. NERDC Press.

Mcmillen, M. (1993).Dropping out of school 1982 - 1992, issues. National Centre for education statistics. Washington, D.C. NCES. 43. 901. 
Osakwe, G., Madunagu, B. I., Usman, H. and Osagie J. (1995). Research findings into reproductive rights of women in Nigeria. International Rights Action Group.

Shertzer, B. \& Stone, S. (1976). Fundamental of guidance. Boston Houghton Mufflin C. (3) 3-91.

Super, D. E. (1957). The Psychology of careers. New York Harper and Row Publishers Inc.

Uba, A. (1983), Theories of Personality. In Uba, A. (Ed) Claerianum Press Ibadan.

Universal Basic Education for Nigeria (1999). Proceedings of the Education Mini Summit Zaria. Ahmadu Bello University Press Ltd.

United Nations International Children Educational Fund (2004). The State of the Worlds children girl's education and development 4, $34-35$.

Wilson, S. B. (1977). Evaluating the impact of receiving University based counselling services on student retention. Journal of counselling psychology. 44, 316 - 320 